\title{
Affective variables and informal digital learning of English: Keys to willingness to communicate in a second language
}

\author{
Ju Seong Lee \\ Education University of Hong Kong \\ Nur Arifah Drajati \\ Universitas Sebelas Maret
}

\begin{abstract}
This study examined the under-researched relationship between informal digital learning of English (IDLE) activities (receptive IDLE activities and productive IDLE activities), affective variables (grit, motivation, self-confidence and second language speaking anxiety) and willingness to communicate in a second language. Data $(N=183)$ were collected through a questionnaire from one state university in an English-as-a-foreign-language Indonesian context. The results showed that students' willingness to communicate correlated significantly with all of the IDLE activities and affective variables. However, only productive IDLE activities, grit, self-confidence, and motivation were identified as the significant predictors of students' willingness to communicate. Findings suggest that students' IDLE engagement and affective states play a significant role in a second language communication. In particular, pedagogical benefits of affective variables (e.g., grit, selfconfidence, and motivation) and productive IDLE activities should be emphasised to facilitate students' willingness to communicate in a second language. These results will broaden current knowledge of IDLE and second language communication behaviour, which can contribute to bridging the interdisciplinary gap between computer assisted language learning, second language acquisition, and psychology.
\end{abstract}

\section{Introduction}

Informal digital learning of English (IDLE) has garnered much research attention in the field of computer assisted language learning due to its linguistic, cognitive, and affective benefits of second language (L2) learning (Lai, 2017; Lee, 2019a). More recent studies (Lee, 2019b; Lee \& Dressman, 2018) have found that diverse IDLE practice — which engages in both form- and meaning-focused L2 learning — plays a vital role in enhancing students' affective variables (e.g., anxiety and motivation) and willingness to communicate in L2 (L2 WTC).

However, the relationship among IDLE activities, affective variables and L2 WTC remains an area for exploration. Research on IDLE and affective variables has focused mainly on motivation, self-confidence, and L2 speaking anxiety, overlooking grit, which is deemed one of the positive affective factors for academic achievement in mainstream education and psychology (Duckworth, 2017). Hence, this study aimed to examine the under-researched relationship between IDLE activities, affective variables (grit, motivation, self-confidence, and anxiety), and L2 WTC. Along with research and pedagogical implications, these results will broaden current knowledge of IDLE and L2 WTC, which can contribute to bridging the interdisciplinary gap between computer assisted language learning, second language acquisition, and psychology.

\section{Literature review}

\section{Informal digital learning of English}

With increased opportunities and affordances for L2 learning due to dramatic advances in mass media and technology, language learning and teaching beyond the classroom has garnered recent research attention in the field of computer assisted language learning within second language acquisition (Benson \& Reinders, 2011; Nunan \& Richards, 2015). Grounded broadly in Benson's (2011) and Reinders and Benson's (2017) learning beyond the classroom model, several computer assisted language learning oriented studies such as extramural English (Sundqvist \& Sylvén, 2016), recreational language learning (Chik \& Ho, 2017), out-of-class autonomous language learning with technology (Lai, 2017), and IDLE (Lee, 2019a, 2019b; Lee \& Dressman, 2018), have provided conceptual and empirical support for four 
dimensions of the learning beyond the classroom in regard to location (e.g., inside or outside classroom), formality (e.g., formal or informal), pedagogy (e.g., instructed or non-instructed), and locus of control (e.g., self-directed or other-directed). More detailed conceptualisation is provided in Benson (2011) and Reinders and Benson (2017).

IDLE has received recent attention in the EFL context. It can be understood as self-directed English learning activities beyond the classroom in informal digital environments that are not structured nor driven by a formal teacher (Lee, 2019b). In other words, EFL learners autonomously use various digital resources such as: speech-to-text software; blogs; online communities; social media; and massive, multiplayer online role-playing games (MMORPG), to support their own L2 learning independent of formal instruction (Sockett \& Toffoli, 2012). However, if EFL learners engage in L2 learning in virtual environments (e.g., MMORPG) but their activities are structured or motivated by teachers or teacher researchers, it is not considered as IDLE (e.g., Reinders \& Wattana, 2015).

Congruent with other similar learning beyond the classroom research, previous studies have found IDLE to enhance linguistic factors, such as vocabulary (Lee, 2019a; Jensen, 2017; Sockett \& Toffoli, 2012; Sundqvist, 2019; Sundqvist \& Wikström, 2015), reading (Cole \& Vanderplank, 2016) and speaking (Lee \& Dressman, 2018); cognitive performance, such as scores in formal testing (Lai, Zhu, \& Gong, 2015; Sundqvist \& Wikström, 2015) and the standardised English test (Lee, 2019b; Kondo et al., 2012); and affective dimensions of L2 learning, such as motivation (Sundqvist \& Sylvén, 2016), confidence (Lai et al., 2015), and L2 WTC (Lee \& Dressman, 2018). Based on Lai et al.'s (2015) analytic framework, Lee (2019a, 2019b) and Lee and Dressman (2018) have highlighted the importance of the quality (diverse engagement in IDLE) of the informal learning experience that is associated with different language learning outcomes. Their research showed quality - which balances between form- and meaning-focused IDLE activities - is significantly related to L2 outcomes such as vocabulary, speaking, and L2 WTC.

These studies also revealed that EFL students generally engage in receptive IDLE activities (RIA) and productive IDLE activities (PIA). Specifically, RIA pays attention to understanding something in English, such as listening to English songs or watching English movies or dramas without a real interlocutor (Krashen, 1982). In contrast, PIA is devoted to producing communication in English, such as chatting with others via Facebook and sharing such content with others (e.g., sharing viral YouTube videos) which involves real interlocutors (Swain, 1985).

\section{Willingness to communicate in second language}

McCroskey and Baer (1985) provided the first WTC model to account for how individual attributes influence first language communication. Since the bridge was established between first language WTC and second language acquisition in the 1990s, L2 WTC has been often theorised as "a readiness to enter into the discourse at a particular time with a specific person or persons, using a L2" (MacIntyre, Dornyei, Clement, \& Noels, 1998, p. 547). Underpinned by MacIntyre et al.'s (1998) theoretical framework, L2 WTC studies have examined why L2 learners are willing or unwilling to communicate in L2 due to traitlike perspectives, such as personality (MacIntyre \& Charos, 1996), self-confidence (Yashima, 2002), motivation and attitude (Hashimoto, 2002), and situation-specific perspectives, such as interlocutors (Cao \& Philip, 2006) and classroom situations (Peng \& Woodrow, 2010). These studies have empirically found a positive association between L2 WTC and second language acquisition with respect to risk-taking (Oxford, 1997), autonomous learning (Derwing, Munro \& Thomson, 2008), L2 proficiency (Yashima, 2002) and lack of L2 anxiety (Cha \& Kim, 2013).

In recent year, an increased cross-cultural communication in a range of digital environments has established the link between L2 WTC and computer assisted language learning. While earlier studies (Freiermuth \& Jarrell, 2006; Kissau, McCullough, \& Pyke, 2010; Reinders \& Wattana, 2014, 2015) looked at the effects of computer assisted language learning on L2 WTC in classroom or lab settings, recent studies (Lee, 2019c; Lee \& Dressman, 2018) have begun to examine its relationship in the IDLE setting. These studies indicated that technology-enhanced L2 activities play a vital role in influencing students' affective variables such as anxiety, motivation, and L2 WTC. 


\section{Affective variables}

In second language acquisition, affective variables such as motivation, self-confidence, and L2 speaking anxiety play a critical role in influencing L2 learners' performance. For instance, motivation has been recognised as an important source for starting and sustaining L2 learning (Dörnyei, 2005). Gardner (1985, 2001, 2010) identified three elements of motivation: (1) motivational intensity (e.g., striving to learn the target language), (2) desire for L2 learning (e.g., wanting to successfully learn the language), and (3) attitudes toward L2 learning (e.g., perceiving language learning as satisfying). Gardner also pointed out that motivation is positively associated with L2 learning and acquisition. Self-confidence has been found to contribute to having learners hold a positive perception of L2 communicative competence, which can lead to the development of actual communicative proficiency (Clément, Dörnyei, \& Noels, 1994; MacIntyre et al., 1998; Pyun, Kim, Cho, \& Lee, 2014). With regard to L2 speaking anxiety, McCroskey (1978) conceptualised it as "an individual's level of fear or anxiety associated with either real or anticipated (oral) communication with another person or persons" (p. 192). Previous studies have indicated that individuals with a high L2 speaking anxiety tend to have a lower level of motivation about L2 learning (Gardner, Day, \& MacIntyre, 1992) and become hesitant to communicate in L2. As a result, this form of anxiety negatively affects L2 oral skill development (Horwitz, Horwitz, \& Cope, 1986).

In the field of psychology and mainstream education, grit, which is conceptualised as "perseverance and passion for long-term goals" (Duckworth, Peterson, Matthews, \& Kelly, 2007, p. 1087), has been generally found to be one of the reliable predictors for successful people in various fields. Although there are some recent research calling into question the validity of grit scale and the role of grit in predicting performance and success (e.g., Credé, Tynan, \& Harms, 2017), several grit studies have found that grittier individuals (e.g., e-learning university students, senior students in public high school, and effective novice teachers in low-income districts) are likely to study and work harder and longer than those who are not. This has generally led to high performance (Aparicio, Bacao, \& Oliveira, 2017; Duckworth, 2017; Duckworth, Kirby, Tsukayama, Berstein, \& Ericsson, 2011; Duckworth et al., 2007; Duckworth \& Quinn, 2009; Eskreis-Winkler, Shulman, Beale, \& Duckworth, 2014; Robertson-Kraft \& Duckworth, 2014). Recently, Keegan (2017) attempted to explore the relationship between grit and second language acquisition from a pedagogical perspective. Although she asserted, "the grittier the language learner, the better" (Keegan, 2017, p. 9), it has yet to be empirically examined to what extent grit can play a role in second language acquisition. In this study, grit is considered as an affective variable, as this individual trait seems closely aligned with three components of Gardner's Socio-Educational Model (Gardner, 1985, 2001), for example, having a strong desire and maintaining a positive attitude to learn and master the target language, which requires a long-term commitment.

Having reviewed the aforementioned studies, three research gaps are particularly noticeable. First, although we know that diverse IDLE practice and affective variables are significantly associated with L2 WTC, the relationship among other types of IDLE activities (RIA and PIA), affective variables (including grit) and L2 WTC constitute unexplored research terrain. Second, to date, our knowledge of IDLE and affective variables has concentrated primarily on motivation, self-confidence, and L2 speaking anxiety, leaving out grit. Moreover, our understanding of grit in second language acquisition is only just developing. Finally, although most IDLE-related studies have been conducted in the EFL context of Europe (Sockett \& Toffoli, 2012; Sundqvist \& Sylvén, 2016), East Asia (Lee \& Dressman, 2018; Lai et al., 2015), and Latin America (Cole \& Vanderplank, 2016), little attention has been paid to South-east Asian settings, such as Indonesia, where students' IDLE practice is not fully recognised in the literature (cf. Lamb, 2004, 2013; Smith, Kuchah, \& Lamb, 2018). That being said, tapping into computer assisted language learning, second language acquisition, and psychology, this study addresses two research questions:

1. To what extent do IDLE activities and affective variables correlate to students' L2 WTC?

2. Which variables, of the two IDLE activities and four affective variables, are significant predictors of the students' L2 WTC? 


\section{Methods}

\section{Participants and context}

A total of 183 Indonesian EFL students (average age 21.19 years, ranging from 18 - 36 years) from one state university in the Central Java region of Indonesia took part in the survey. At the time of this study, 111 students (60.7\%) had been studying English for more than 10 years, 50 students (27.2\%) for 6 to 9 years, and 22 students $(12.1 \%)$ for less than 5 years. The cohort consisted of 37 males $(20.2 \%)$ and 146 females $(79.8 \%)$. They were all English major students, with a mix of 17 first year $(9.3 \%), 41$ second year $(22.4 \%), 41$ third year $(22.4 \%), 24$ fourth year $(13.1 \%)$, and 60 graduate students $(32.8 \%)$. In accordance with the Common European Framework of Reference for Languages (http://www.coe.int/t/dg4/linguistic/Source/Framework_en.pdf), instructors (including the second author) evaluated students' English levels as B2 (upper intermediate). At the time of this study, students were taking courses in English (e.g., Academic Speaking and ELT Curriculum Development).

\section{Instrument}

The questionnaire consisted of four parts. The question items of the first part, designed to elicit the two types of IDLE activities (RIA and PIA), were developed with reference to Lee (2019a, 2019b, 2019c). Answers were rated on a 5-point Likert scale ranging from 1 never to 5 very often (many times per day). Items for the L2 WTC scale (Part 2) were adopted from previous studies (Peng, 2013; Ryan, 2009; Yashima, 2009), and used to assess students' L2 WTC in two different communicative environments, inside the classroom (4 items) and outside the classroom (4 items), on a 5-point Likert scale where 1 represented definitely not willing and 5 represented definitely willing. Part 3 asked participants to answer 30 items concerning the four affective variables: grit ( 8 items), motivation ( 8 items), self-confidence ( 8 items), and L2 speaking anxiety (6 items). Items for the grit scale were adopted from Duckworth and Quinn (2009) and used to measure participants' perseverance of effort and consistency of interests on a 5point Likert scale ranging from 1 not like me at all to 5 very much like me. Motivation was assessed pertaining to participants' motivational intensity, desire to learn English, and attitudes toward studying English by means of Attitude/Motivation Test Battery (AMTB) developed by Gardner (1985) and Gardner, Tremblay, and Masgoret (1997). Items for motivation were adopted and modified from Pyun et al. (2014). Items for the self-confidence scale were adopted from Pyun et al. (2014) and employed to measure the degree of confidence perceived by participants when understanding and communicating to others in English. Finally, questions concerning L2 speaking anxiety were adopted and modified from Pyun et al. (2014) as well as the foreign language classroom anxiety scale developed by Horwitz et al. (1986) and used to assess the degree to which participants feel anxious about speaking English. Responses to questionnaire items in motivation, self-confidence, and L2 speaking anxiety scales were rated on a 5-point Likert scale ranging from 1 strongly disagree to 5 strong agree. Question items (Parts 1 - 3) are presented in Appendix A. The fourth part of the questionnaire was used to obtain participants' demographic information, such as age, length of time learning English, academic year, gender, and major.

Three second language acquisition researchers checked the content validity of the instrument. A pilot test was then undertaken with a group of 10 Indonesian EFL students, which resulted in the refinement of the English questionnaire items. Negatively-keyed items such as the grit items $5-8$ (e.g., "New ideas and projects sometimes distract me from previous ones") and the motivation item 4 ("I don't really have a great desire to learn English") were reverse-scored. Additionally, an exploratory factor analysis (using a principal axis factor analysis with varimax rotation) was conducted to assess the construct validity of the seemingly identical L2 WTC and affective variables, followed by the reliability test with Cronbach's alpha. Consequently, 38 items covered constructs related to L2 WTC (8 items; factor loading ranging from 0.51 to $0.73 ; \alpha=0.86$ ), grit ( 8 items; factor loading ranging from 0.54 to $0.83 ; \alpha=0.74$ ), motivation ( 8 items; factor loading ranging from 0.45 to $0.75 ; \alpha=0.75$ ), self-confidence ( 8 items; factor loading ranging from 0.61 to $0.79 ; \alpha=0.89$ ), and L2 speaking anxiety ( 6 items; factor loading ranging from 0.62 to $0.83 ; \alpha=0.90$ ). Finally, the construct validity and internal reliability for RIA ( 7 items; factor loading ranging from 0.41 to $0.75 ; \alpha=0.74$ ) and PIA ( 6 items; factor loading ranging from 0.33 to $0.86 ; \alpha=0.81$ ) were also checked. These data showed an acceptable construct validity and internal reliability for each subscale in the questionnaire (Cronbach, 1951; Hair, Anderson, Tatham \& Black, 1998). 


\section{Data collection}

After obtaining the institutional review board's approval, the nature of the study, including purposes, procedures, benefits/risks, and rights of participants, was explained to potential participants by the second author (instructor). Only students who had submitted their consent forms were allowed to respond to the questionnaire during the 2017 fall and 2018 spring semester periods.

Lee (2019b) previously observed that some Korean EFL students, who had studied English mostly through formal educational systems, could have become conceptually confused about the truly independent nature of the IDLE. Likewise, since a majority of the Indonesian respondents (60.7\%) had learned English as their second language for at least 10 years, an accurate line between formal and informal language experiences might have seemed difficult to draw in their own perceptions (Lai, 2017). For instance, some activities reflected in RIA and PIA items such as "listening to English language news programs online or TV" and "sending an email to others in English" could be carried out as a part of the preparation for classes and required by teachers and language programs.

In order to make IDLE, as measured by RIA and PIA questionnaires in this study, genuinely independent from formal educational experiences, the second author explained IDLE practices in detail with relevant examples prior to administering the survey. Thus, students were informed that IDLE indicates autonomous English learning activities in extramural digital environments (e.g., playing games in English and watching English comics online or TV). In contrast, formal digital learning of language signals teacher-suggested or initiated English learning routines (e.g., reading Wikipedia articles or watching TED Talks to complete homework).

\section{Data analysis}

Descriptive statistics were analysed using the IBM SPSS Statistics 25 program. Subsequently, a Pearson's Correlation analysis was conducted to examine the relationship among seven variables (RIA, PIA, grit, motivation, self-confidence, L2 speaking anxiety, and L2 WTC). This was followed by linear regressions analysis to determine the influence of IDLE activities (RIA and PIA) and affective variables (grit, motivation, self-confidence, and L2 speaking anxiety) on L2 WTC.

\section{Results}

\section{Descriptive statistics}

Table 1 presents descriptive data on the students' IDLE activities, affective variables, and L2 WTC. It shows that participants engaged more in RIA $(M=3.20, S D=0.71)$ than PIA $(M=2.48, S D=0.77)$. With respect to affective variables, participants responded with above-average agreement to grit $(M=$ 3.27, $S D=0.52)$, motivation $(M=4.15, S D=0.42)$, self-confidence $(M=3.95, S D=0.51)$, and L2 speaking anxiety $(M=3.07, S D=0.85)$ scales. This suggests that students had fairly high levels of grit, motivation, self-confidence and L2 speaking anxiety with regard to learning or using English. As regards L2 WTC, the mean score $4.03(S D=0.62)$ indicates that, overall, participants were generally willing to communicate in English.

Table 1

Descriptive data on IDLE activities, affective variables, and L2 WTC

\begin{tabular}{lllll}
\hline Variables & Min & Max & $M$ & $S D$ \\
\hline RIA & 1 & 5 & 3.20 & 0.71 \\
PIA & 1 & 5 & 2.48 & 0.77 \\
Grit & 1 & 5 & 3.27 & 0.52 \\
Motivation & 1 & 5 & 4.15 & 0.42 \\
Self-confidence & 1 & 5 & 3.95 & 0.51 \\
L2 speaking anxiety & 1 & 5 & 3.07 & 0.85 \\
L2 WTC & 1 & 5 & 4.03 & 0.62 \\
\hline
\end{tabular}




\section{Correlation analysis}

This section addresses research question 1. The correlation analysis shown in Table 2 indicates that students' L2 WTC correlated significantly with all of the IDLE activities and affective variables. That is, L2 WTC was positively associated with RIA $(r=0.25, p<0.01)$, PIA $(r=0.44, p<0.01)$, grit $(r=0.44$, $p<0.01)$, motivation $(r=0.42, p<0.01)$, and self-confidence $(r=0.49, p<0.01)$, and negatively associated with L2 speaking anxiety $(r=-0.41, p<0.01)$.

Table 2

Correlations among variables

\begin{tabular}{|c|c|c|c|c|c|c|c|}
\hline Variables & RIA & PIA & Grit & Motivation & Confidence & Anxiety & L2 WTC \\
\hline RIA & 1 & $0.62 * *$ & $0.25 * *$ & $0.22^{* *}$ & $0.25^{* *}$ & $-0.25^{* *}$ & $0.25 * *$ \\
\hline PIA & & 1 & $0.32 * *$ & $0.34 * *$ & $0.36^{* *}$ & $-0.34 * *$ & $0.44 * *$ \\
\hline Grit & & & 1 & $0.30 * *$ & $0.30 * *$ & $-0.34 * *$ & $0.44 * *$ \\
\hline Motivation & & & & 1 & $0.49 * *$ & $-0.28 * *$ & $0.42 * *$ \\
\hline Confidence & & & & & 1 & $-0.54 * *$ & $0.49^{* *}$ \\
\hline Anxiety & & & & & & 1 & $-0.41 * *$ \\
\hline L2 WTC & & & & & & & 1 \\
\hline
\end{tabular}

Note: Confidence $=$ self-confidence, Anxiety $=$ L2 speaking anxiety

$* * p<0.01$

\section{Regression statistics}

This section deals with research question 2. In order to examine which of the variables (IDLE activities and affective variables), if any, predicts students' L2 WTC, a linear regression was carried out with L2 WTC submitted as the dependent variable. The results show that PIA $(\beta=0.24, p<0.01)$, grit $(\beta=0.23$, $p<0.01)$, self-confidence $(\beta=0.22, p<0.01)$, and motivation $(\beta=0.15, p<0.05)$ were identified as the significant predictors of students' L2 WTC. The other variables (RIA and L2 speaking anxiety) were found not to be determinants of students' L2 WTC. As presented in Table 3, approximately $38 \%$ of the variability of the L2 WTC score (Adjusted $R^{2}$ ) was explained by PIA, grit, self-confidence, and motivation. These results suggest that PIA, grit, self-confidence, and motivation significantly predicted students' L2 WTC.

Table 3

Linear regression of IDLE and affective variables on $L 2$ WTC

\begin{tabular}{|c|c|c|c|c|c|c|}
\hline \multirow[t]{2}{*}{ Model } & \multirow[t]{2}{*}{ Predictors } & \multicolumn{3}{|c|}{ Regression coefficient } & \multirow[t]{2}{*}{$T$} & \multirow[t]{2}{*}{$\rho$} \\
\hline & & $\beta$ & $S E$ & $\beta$ & & \\
\hline \multirow[t]{7}{*}{ WTC } & Constant & 1.13 & 0.55 & & 2.04 & \\
\hline & RIA & -0.06 & 0.07 & -0.07 & -0.92 & ns \\
\hline & PIA & 0.19 & 0.06 & 0.24 & 3.01 & $* *$ \\
\hline & Grit & 0.27 & 0.08 & 0.23 & 3.52 & $* *$ \\
\hline & Motivation & 0.22 & 0.10 & 0.15 & 2.16 & * \\
\hline & Confidence & 0.27 & 0.09 & 0.22 & 2.86 & $* *$ \\
\hline & Anxiety & -0.07 & 0.05 & -0.10 & -1.41 & $\mathrm{~ns}$ \\
\hline
\end{tabular}

Note: $n=183 ; R^{2}=.63$; Adjusted $R^{2}=.38 ; \mathrm{F}(6,176)=19.36, \rho<0.001 ; * p<0.05 ; * * p<0.01 ; \mathrm{ns}=\mathrm{not}$ significant

As exhibited in Table 4, hierarchical multiple regression was also conducted in order to control potential confounding variables. Demographic variables (age, gender, academic year, and length of time learning English) were entered as Block 1, and RIA, PIA, grit, motivation, self-confidence, and L2 speaking anxiety were entered as Block 2 . Analysis took L2 WTC as the dependent variable. In Model 1 , age $(\beta=$ $0.20, p<0.05)$ and length of time learning English $(\beta=0.15, p<0.05)$ were statically significant. In Model 2, PIA $(\beta=0.22, p<0.01)$, grit $(\beta=0.22, p<0.01)$, self-confidence $(\beta=0.20, p<0.05)$ and motivation $(\beta=0.14, p<0.05)$ were the predictor variables that made a significant contribution to the model, while four demographic variables $(p>0.05)$, L2 speaking anxiety $(p>0.05)$, and RIA $(p>0.05)$ were not significant. 
Table 4

Hierarchical regression analysis for variables predicting L2 WTC

\begin{tabular}{lrrrr} 
& \multicolumn{3}{c}{ Model 1 } & \multicolumn{2}{c}{ Model 2 } \\
\cline { 2 - 5 } Constant & $\mathrm{B}(S E)$ & $\beta$ & $\mathrm{B}(S E)$ & $\beta$ \\
Age & $2.45(0.40)$ & & $0.79(0.59)$ & 0.01 \\
Gender & $0.04(0.02)$ & $0.20^{*}$ & $0.01(0.02)$ & 0.08 \\
Academic year & $0.10(0.11)$ & 0.07 & $0.12(0.09)$ & 0.07 \\
Length of time learning English & $0.03(0.04)$ & 0.07 & $0.03(0.03)$ & 0.09 \\
\hline RIA & $0.08(0.04)$ & $0.15^{*}$ & $0.05(0.03)$ & -0.05 \\
PIA & & & $-0.04(0.06)$ & $0.22^{* *}$ \\
Grit & & & $0.17(0.07)$ & $0.22^{* *}$ \\
Motivation & & & $0.21(0.08)$ & $0.14^{*}$ \\
Self-confidence & & & $0.25(0.10)$ & $0.20^{*}$ \\
L2 speaking anxiety & & 0.09 & & -0.12 \\
\hline$R^{2}$ & & & & 0.42 \\
Change of $R^{2}$ & & & & 0.33 \\
\hline
\end{tabular}

Note: $* p<0.05 ; * * p<0.01$

\section{Discussion}

This study examined the relationship between IDLE activities (RIA and PIA), affective variables (grit, motivation, self-confidence and L2 speaking anxiety), and L2 WTC among Indonesian EFL learners. In particular, this study attempted to investigate to what extent students' IDLE activities and affective states are associated with their L2 WTC. The results showed that students' L2 WTC correlated significantly with all of the IDLE activities and affective variables. These results corroborate previous findings regarding a significant relationship between L2 WTC and IDLE (Lee \& Dressman, 2018), as well as with L2 learning outcomes (e.g., L2 oral performance and L2 WTC) and affective variables such as motivation (Dörnyei, 2005; Gardner, 1985, 2001, 2010), self-confidence (Clément et al., 1994; MacIntyre et al., 1998), and L2 speaking anxiety (Horwitz et al., 1986). However, it is worth noting that correlations between variables do not imply causation: one variable (e.g., IDLE activities or affective variables) may not necessarily cause the other (e.g., L2 WTC).

The study also found that only PIA, grit, self-confidence, and motivation were found to significantly predict students' L2 WTC, while the other variables (RIA, L2 speaking anxiety, and demographic variables) were found not to be determinants of students' L2 WTC. Whereas several previous studies have already identified a significant association between L2 WTC and affective variables such as motivation (Dörnyei, 2005; Gardner, 1985, 2001, 2010) and self-confidence (Clément et al., 1994; MacIntyre et al., 1998), this study provides new empirical evidence of the relationship between L2 WTC and grit. The finding concerning grit supports previous studies, which found that grit was a significant predictor of retention and performance in e-learning systems (Aparicio et al., 2017) in public high schools (Eskreis-Winkler et al., 2014), National Spelling Bee contests (Duckworth et al., 2007, 2011), West Point (Duckworth, 2017; Duckworth et al., 2007), the military (Eskreis-Winkler et al., 2014), and low-income school districts (Robertson-Kraft \& Duckworth, 2014). However, these previous studies were conducted in the field of psychology and mainstream education, which did not specifically address second language acquisition or foreign language learning. In that regard, this study contributes to offering new empirical insights into the field of second language acquisition, one in which grit could serve as a significant predictor of L2 WTC - a predictive power of linear regression model that had not been assessed in previous studies (e.g., Keegan, 2017).

The result regarding PIA is also aligned with an earlier finding, which indicated that diverse engagement in IDLE (diversity of IDLE) was a significant predictor of Korean EFL learners' L2 WTC (Lee \& Dressman, 2018). However, the researchers gauged an L2 WTC level only in the IDLE context, neglecting the other dimensions of L2 WTC, such as L2 WTC inside and outside the classroom (Peng, 2013; Ryan, 2009; Yashima, 2009). On these grounds this study offers two additional insights into the fields of computer assisted language learning and second language acquisition. First, whereas previous research (Lee \& Dressman, 2018) found that diverse engagement in IDLE involving both form- and 
meaning-focused IDLE activities was significantly related to L2 WTC in a digital context (IDLE setting), this study provides new empirical evidence that another type of IDLE engagement (PIA) is significantly associated with L2 WTC in non-digital contexts (inside and outside the classroom). This result suggests that students' engagement in PIA (e.g., chatting with foreigners in English on social media and posting English comments to a friend's wall on Facebook) is significantly associated with L2 WTC in non-digital settings (e.g., students are willing to communicate in English both inside and outside the English class). Second, congruent with the findings of previous studies conducted in a Korean EFL context (e.g., Lee \& Dressman, 2018), this study also found that a productive-oriented IDLE activity was a significant predictor of Indonesian EFL learners' L2 WTC. This finding contributes to advancing our understanding of this phenomenon in two Asian contexts (i.e., Indonesia and Korea).

\section{Pedagogical implications and recommendations}

Results of this study have implications for second language acquisition, and psychology researchers and practitioners. From a research standpoint, although the significance of L2 learners' affective traits (e.g., motivation, self-confidence, and L2 speaking anxiety) on L2 WTC have previously been documented, there has been a limited effort in linking grit and L2 WTC in the field of second language acquisition. This study has somewhat filled that void and could serve as a catalyst for future researchers in conducting interdisciplinary research between second language acquisition and psychology. Nonetheless, we also need to be cautious about advocating the significance of grit in educational practice; for example, Credé et al. (2017) indicated that one sub-facet of grit (i.e., perseverance of effort) appeared more important than grit itself. The researchers also suggested that grit substantially overlapped with the much older concept of conscientiousness. Regarding implications for pedagogy, given that three affective variables (self-confidence, motivation, and grit) and PIA were identified as the significant predictors of students' L2 WTC in non-digital settings, it is important for L2 teachers to recognise these variables as important components of second language acquisition. More significantly, teachers need to make an informed decision on how these variables can be leveraged to promote L2 learners' communication orientations and behaviours. Informed by these findings, and previous studies, we propose some pedagogical recommendations for $\mathrm{L} 2$ practitioners and school administrators.

As regards affective variables, practitioners can provide three instructional supports (Duckworth, 2017; Keegan, 2017; Lai, 2017; Lee, 2019c). At the outset, L2 teachers can provide students with emotional support by placing a higher value on their constant efforts in speaking in English compared to perfect performance or good grades. Teachers should be continuously encouraging risk-taking and setting up scenarios where communication is emphasised over correct language and highlighting and correcting errors. As a result students may perceive linguistic errors as acceptable and normal and, ultimately, become less anxious but more confident about speaking in English. Consequently, they are more likely to become motivated and seek opportunities to use L2 in non-digital environments.

Second, L2 teachers can provide students with cognitive and meta-cognitive resources by sharing telling examples of gritty world figures or L2 learners. For example, Fannin (2008) recounts the story of Jack Ma, who mentioned:

[During adolescent years] I got interested in learning English. I rode my bike for 40 minutes every morning, rain or snow, for eight years to a hotel near the city of Hangzhou's West Lake district ... I showed [foreign tourists] around as a free guide and practiced my English.

Although he had failed university entrance exam twice and been rejected from several job applications, Jack Ma persisted in teaching himself English mainly in the Chinese EFL context and eventually became an English teacher, the job that he was (and still is) passionate about (Whiting, 2018). Later, using the same principle of grit, he set up another long-term goal of becoming an entrepreneur and founded the Alibaba Group despite a series of setbacks and failures (Klebnikov, 2018). For L2 students, Jack Ma's successful informal language learning stories and strategies can be inspiring, which can help them remain committed to L2 learning despite setbacks and failures. In a more tangible way, teachers can share their own personal anecdotes and strategies with students, highlighting the critical role of grit with regard to their L2 learning. 
Third, teachers can offer behaviour support by explicitly teaching how to develop grit skills through inclass or extracurricular activities. It has often been reported that South-east Asian EFL students tend to feel anxious and become unwilling to communicate in English inside the classroom and in IDLE contexts because of individual, contextual, and sociopolitical factors (e.g., interlocutors, fear of losing face in public, or national policy) (Hsu, 2015; Lee, 2019c; Zhong, 2013). Thus, EFL teachers and school administrators may consider integrating the three affective variables of self-confidence, motivation, and grit into their institutional programs to help students overcome internal or external barriers and thereby become more willing to communicate in English (Duckworth, 2017; Keegan, 2017).

With respect to PIA, teachers can design and implement productive-oriented IDLE activities as a part of extramural activities. More specifically, in reference to Dressman's (2017) recommendations, teachers can implement IDLE-integrated activities appropriate to their own educational context on a 3-stage continuum. In the first stage, technology can be incorporated into lesson plans in the classroom as a supplementary function. In the second stage, teachers can involve students in extracurricular activities outside the classroom that would allow them to learn and use a range of digital technology in the process of completing tasks. In the final stage, based on the assessment of students' possession of digital devices, plus learning needs and interest, L2 teachers can help students create their own IDLE environment in which they can continuously learn and use English in various IDLE spaces without a teacher's intervention. It is worthwhile to note that the affective variables of grit, motivation, and self-confidence, which were found to be significant predictors of students' L2 WTC in this study, can play a vital role in initiating and sustaining students' IDLE activities during the third stage. Although this study indicates that young EFL students are practicing various IDLE activities (e.g., online communities and social media), it is important to bear in mind that not every IDLE engagement may yield an equal result (see also Lee, 2019a; Lee \& Dressman, 2018). For instance, although students spent a great deal of time involved with RIA (e.g., watching English language movies or dramas), this did not lead to promoting their L2 WTC. Instead, PIA (e.g., chatting with others in English via social media) contributed significantly to encouraging students' L2 WTC in a positive manner. This finding can help L2 teachers make an informed instructional decision about how to effectively design and implement IDLE activities for maximising EFL students' language skills. Consequently, during the first and second stages, IDLE could serve as an important supplement to formal language learning. The ultimate pedagogical goal for L2 teachers is to accomplish the third stage and help students construct their own IDLE environment in which they can continuously learn and use English in various IDLE spaces independent of formal L2 instruction.

\section{Conclusion}

The current study set out to examine the relationship as to whether or to what extent students' IDLE activities (RIA and PIA) and affective states (grit, motivation, self-confidence, and anxiety) are associated with their L2 WTC. This study showed that students' L2 WTC correlated significantly with all IDLE activities and affective variables. However, only PIA, grit, self-confidence and motivation were identified as significant predictors of students' L2 WTC. These results suggest that EFL students' IDLE engagement and affective states play a significant role in L2 WTC. In particular, pedagogical benefits of affective variables (grit, self-confidence, and motivation) and PIA should be emphasised to facilitate students' L2 WTC in EFL contexts.

Nevertheless, we acknowledge several drawbacks in this study. First, since data were gathered solely from English majors enrolled in one Indonesian university in a particular geographic region, these results may not represent the entire population of Indonesia. Therefore, a future study should recruit more diverse students in terms of major, institution, and geographic location in order to strengthen the current findings. Moreover, since our study only examined EFL students, the results of the study may not necessarily extrapolate to other languages or other cultural contexts. Second, the results were exclusively based on self-reported data, so additional data such as semi-structured interviews or focal group discussions may be necessary to provide an accurate understanding of the current data. Third, although this quantitative study may advance our understanding of the phenomenon in question, it failed to gain a deeper understanding of how and through what process PIA, grit, self-confidence, and motivation were conducive to facilitating students' L2 WTC. For a future study, we may need to obtain more qualitative data in order to analyse the data with more nuance and precision. 
Fourth, while the current study investigated L2 WTC in relation to IDLE and affective variables, it did not consider participants' past experiences with IDLE activities. Further, it did not empirically verify whether L2 WTC could lead to improving students' actual L2 communicative abilities. Therefore, a future study may investigate if there is any association between affective variables, IDLE activities, L2 WTC, and L2 speaking/writing while taking the prior IDLE experience variable into account. Fifth, based on previous studies (e.g., Lee \& Dressman, 2018), a unidirectional hypothesis was verified in this study. However, the other way around also seems equally plausible: for example, L2 WTC enables and facilitates actual engagement in each new active exchange. A future study may consider examining whether L2 WTC could predict IDLE (RIA and PIA) and affective variables (grit, motivation, and selfconfidence). Last but not least, although the current study showed that both three affective variables (grit, self-confidence, and motivation) and PIA were significantly associated with L2 WTC, a future study may consider exploring whether the affective variables mediate the relationship between PIA and L2 WTC. This could offer other important pedagogical and research insights. For example, extensive IDLE experience in communication in L2 (both receiving and producing oral and written messages) could help to enhance students' grit, self-confidence, and motivation, and promotes readiness to engage in further communications.

Despite these limitations, this study unraveled the under-researched relationship between IDLE activities, affective variables, and L2 WTC. At the same time, it expanded the scope of the current inquiry to include grit. Therefore, this study addresses important research gaps and contributes to improving our understanding of IDLE activities in connection with affective variables and L2 WTC. We hope that this study is a modest step toward more interdisciplinary endeavours. Further research projects could explore such relationships in other contexts.

\section{References}

Aparicio, M., Bacao, F., \& Oliveira, T. (2017). Grit in the path to e-learning success. Computers in Human Behavior, 66, 388-399. https://doi.org/10.1016/j.chb.2016.10.009

Benson, P. (2011). Language learning and teaching beyond the classroom: An introduction to the field. In P. Benson \& H. Reinders (Eds.), Beyond the language classroom: The theory and practice of informed language learning and teaching (pp. 7-16). New York, NY: Palgrave Macmillan.

Benson, P., \& Reinders, H. (Eds.) (2011). Beyond the language classroom. New York, NY: Palgrave Macmillan.

Cao, Y., \& Philip, J. (2006). Interactional context and willingness to communicate: a comparison of behavior in whole class, group and dyadic interaction. System, 34(4), 480-493. https://doi.org/10.1016/j.system.2006.05.002

Cha, J.-S., \& Kim, T.-Y. (2013). Effects of English-learning motivation and language anxiety of the elementary school students on willingness to communicate in English and English speaking. Primary English Education, 19(1), 271-294.

Chik, A., \& Ho, J. (2017). Learn a language for free: Recreational learning among adults. System, 69, 162-171. https://doi.org/10.1016/j.system.2017.07.017

Clément, R., Dörnyei, Z., \& Noels, K. A. (1994). Motivation, self-confidence, and group cohesion in the foreign language classroom. Language Learning, 44(3), 417-448. https://doi.org/10.1111/j.14671770.1994.tb01113.x

Cole, J., \& Vanderplank, R. (2016). Comparing autonomous and class-based learners in Brazil: Evidence for the present-day advantages of informal, out-of-class learning. System, 61, 31-42. https://doi.org/10.1016/j.system.2016.07.007

Credé, M., Tynan, M. C., \& Harms, P. D. (2017). Much ado about grit: A meta-analytic synthesis of the grit literature. Journal of Personality and Social Psychology, 113(3), 492-511. https://doi.org/10.1037/pspp0000102

Cronbach, L. J. (1951). Coefficient alpha and the internal structure of tests. Psychometrika, 16(3), 297334.

Derwing, T., Munro, M., \& Thomson, R. (2008). A longitudinal study of ESL learners' fluency and comprehensibility development. Applied Linguistics, 29(3), 359-380. https://doi.org/10.1093/applin/amm041

Dörnyei, Z. (2005). The psychology of the language learner: Individual differences in second language acquisition. Mahwah, NJ: Lawrence Erlbaum. 
Dressman, M. (2017, October). Informal language acquisition and classroom teaching: Complementary, not competitive, approaches. 2017 Korea TESOL International Conference, Seoul, South Korea.

Duckworth, A. L. (2017). Grit: Why passion and resilience are the secrets to success. Vermilion: Penguin Random House.

Duckworth, A. L., Kirby, T., Tsukayama, E., Berstein, H., \& Ericsson, K. A. (2011). Deliberate practice spells success: Why grittier competitors triumph at the National Spelling Bee. Social Psychological \& Personality Science, 2(2), 174-181. https://doi.org/10.1177/1948550610385872

Duckworth, A. L., Peterson, C., Matthews, M., \& Kelly, D. (2007). Grit: Perseverance and passion for long-term goals. Journal of Personality and Social Psychology, 92(6), 1087-1101. https://doi.org/10.1037/0022-3514.92.6.1087

Duckworth, A. L., \& Quinn, P. D. (2009). Development and validation of the short grit scale (Grit-S). Journal of Personality Assessment, 91(2), 166-174. doi:10.1080/00223890802634290

Eskreis-Winkler, L., Shulman, E. P., Beale, S. A., \& Duckworth, A. L. (2014). The grit effect: Predicting retention in the military, the workplace, school and marriage. Frontiers in Psychology, 5(36). 1-12. https://doi.org/10.3389/fpsyg.2014.00036

Fannin, R. (2008). How I did it: Jack Ma, Alibaba.com. Inc. Retrieved from https://www.inc.com/magazine/20080101/how-i-did-it-jack-ma-alibaba.html

Freiermuth, M., \& Jarrell, D. (2006). Willingness to communicate: Can online chat help? International Journal of Applied Linguistics, 16(2), 189-212. https://doi.org/10.1111/j.1473-4192.2006.00113.x

Gardner, R. C. (1985). Social psychology and second language learning: The role of attitudes and motivation. London: Edward Arnold.

Gardner, R. C. (2001). Integrative motivation and second language acquisition. In Z. Dörnyei, \& R. W. Schmidt (Eds.), Motivation and second language acquisition (pp. 1-19). Honolulu: University of Hawaii Second Language Teaching and Curriculum Center.

Gardner, R. C. (2010). Motivation and second language acquisition: The socio-educational model. New York, NY: Peter Lang.

Gardner, R. C., Day, J. B., \& MacIntyre, P. D. (1992). Integrative motivation, induced anxiety, and language learning in a controlled environment. Studies in Second Language Acquisition, 14(2), 197214. https://doi.org/10.1017/S0272263100010822

Gardner, R. C., Tremblay, P. F., \& Masgoret, A.-M. (1997). Towards a full model of second language learning: An empirical investigation. The Modern Language Journal, 81(iii), 344-362. https://doi.org/10.1111/j.1540-4781.1997.tb05495.x

Hair, J. F., Anderson, R. E., Tatham, R. L., \& Black, W. C. (1998). Multivariate data analysis (5th ed.). Upper Saddle River, NJ: Prentice.

Hashimoto, Y. (2002). Motivation and willingness to communicate as predictors of reported L2 use: The Japanese ESL context. Second Language Studies, 20(2), 29-70.

Horwitz, E. K., Horwitz, M. B., \& Cope, J. (1986). Foreign language classroom anxiety. The Modern Language Journal, 70(2), 125-132. https://doi.org/10.1111/j.1540-4781.1986.tb05256.x

Hsu, W. H. (2015). Transitioning to a communication-oriented pedagogy: Taiwanese university freshmen's views on class participation. System, 49, 61-72. https://doi.org/10.1016/j.system.2014.12.002

Jensen, S. H. (2017). Gaming as an English language learning resource among young children in Denmark. CALICO Journal, 34(1), 1-19. doi:10.1558/cj.29519

Keegan, K. (2017). Identifying and building grit in language learners. English Teaching Forum, 55(3), 19. https://americanenglish.state.gov/files/ae/resource_files/etf_55_3_pg02-09_1.pdf

Kissau, S., McCullough, H., \& Pyke, J. G. (2010). Leveling the playing field: The effects of online second language instruction on student willingness to communicate in French. CALICO Journal, 27(2), 277-297. https://doi.org/10.2307/calicojournal.27.2.277

Klebnikov, S. (2018). Jack Ma is quitting his $\$ 420$ billion company to become a teacher. Here's everything to know about China's richest man. Retrieved from http://time.com/money/5403538/jackma-chinas-richest-man/

Kondo, M., Ishikawa, Y., Smith, C., Sakamoto, K., Shimomura, H., \& Wada, N. (2012). Mobile assisted language learning in university EFL courses in Japan: Developing attitudes and skills for selfregulated learning. ReCALL, 24(2), 169-187. https://doi.org/10.1017/S0958344012000055

Krashen, S. D. (1982). Principles and practice in second language acquisition. Oxford: Pergamon.

Lai, C. (2017). Autonomous language learning with technology beyond the classroom. New York, NY: Bloomsbury Publishing.

Lai, C., Zhu, W., \& Gong, G. (2015). Understanding the quality of out-of-class English learning. TESOL 
Quarterly, 49(2), 278-308. https://doi.org/10.1002/tesq.171

Lamb, M. (2004). It depends on the students themselves: Independent language learning at an Indonesian state school. Language, Culture and Curriculum, 17(3), 229-245. http://eprints.whiterose.ac.uk/1662/

Lamb, M. (2013). 'Your mum and dad can't teach you!': Constraints on agency among rural learners of English in the developing world. Journal of Multilingual and Multicultural Development, 34(1), 1429. https://doi.org/10.1080/01434632.2012.697467

Lee, J. S. (2019a). Informal digital learning of English and second language vocabulary outcomes: Can quantity conquer quality? British Journal of Educational Technology, 50(2), 767-778. https://doi.org/10.1111/bjet.12599

Lee, J. S. (2019b). Quantity and diversity of informal digital learning of English. Language Learning \& Technology, 23(1), 114-126. https://doi.org/10125/44675

Lee, J. S. (2019c). EFL students' views of willingness to communicate in the extramural digital context. Computer Assisted Language Learning. https://doi.org/10.1080/09588221.2018.1535509

Lee, J. S., \& Dressman, M. (2018). When IDLE hands make an English workshop: Informal digital learning of English and language proficiency. TESOL Quarterly, 52(2), 435-445. https://doi.org/10.1002/tesq.422

MacIntyre, P. D., \& Charos, C. (1996). Personality, attitudes, and affect as predictors of second language communication. Journal of Language and Social Psychology, 15(1), 3-26. https://doi.org/10.1177/0261927X960151001

MacIntyre, P. D., Dörnyei, Z., Clément, R., \& Noels, K. A. (1998). Conceptualizing willingness to communicate in a L2: A situational model of L2 confidence and affiliation. The Modern Language Journal, 82(4), 545-562. http://www.jstor.org/stable/330224

McCroskey, J. C. (1978). Validity of the PRCA as an index of oral communication apprehension. Communication Monographs, 45(3), 192-203.

McCroskey, J. C., \& Baer, J. E. (1985, November). Willingness to communicate: The construct and its measurement. Paper presented at the annual convention of the Speech Communication Association, Denver, CO.

Nunan, D., \& Richards, J. C. (Eds.) (2015). Language learning beyond the classroom. New York, NY: Routledge.

Peng, J. E. (2013). The challenge of measuring willingness to communicate in EFL contexts. The Asia Pacific Education Researcher, 22(3), 281-290. https://doi.org/10.1007/s40299-012-0053-x

Peng, J. E., \& Woodrow, L. (2010). Willingness to communicate in English: A model in the Chinese EFL classroom context. Language learning, 60(4), 834-876. https://doi.org/10.1111/j.14679922.2010.00576.x

Pyun, D. O., Kim, J. S., Cho, H. Y., \& Lee, J. H. (2014). Impact of affective variables on Korean as a foreign language learners' oral achievement. System, 47, 53-63. https://doi.org/10.1016/j.system.2014.09.017

Oxford, R. (1997). Cooperative learning, collaborative learning, and interaction: Three communicative strands in the language classroom. The Modern Language Journal, 81(4), 443-456.

Reinders, H., \& Benson, P. (2017). Research agenda: Language learning beyond the classroom. Language Teaching, 50(4), 561-578. https://doi.org/10.1017/S0261444817000192

Reinders, H., \& Wattana, S. (2014). Can I say something? The effects of digital game play on willingness to communicate. Language Learning \& Technology, 18(2), 101-123. http://lit.msu.edu/issues/june2014/reinderswattana.pdf

Reinders, H., \& Wattana, S. (2015). Affect and willingness to communicate in digital game-based learning. ReCALL, 27(1), 38-57. https://doi.org/10.1017/S0958344014000226

Robertson-Kraft, C., \& Duckworth, A. L. (2014). True grit: Trait-level perseverance and passion for longterm goals predicts effectiveness and retention among novice teachers. Teachers College Record, $116(3), 1-27$.

Ryan, S. (2009). Self and identity in L2 motivation in Japan: The ideal L2 self and Japanese learners of English. In Z. Dörnyei, \& E. Ushioda (Eds.), Motivation, language identify and the L2 self (pp. 120143). Bristol: Multilingual Matters.

Smith, R., Kuchah, K., \& Lamb, M. (2018). Learner autonomy in developing countries. In A. Chik, N. Aoki, \& R. Smith (Eds.), Autonomy in language learning and teaching: New research agendas (pp. 12-32). London: Palgrave Macmillan.

Sockett, G., \& Toffoli, D. (2012). Beyond learner autonomy: A dynamic systems view of the informal learning of English in virtual online communities. ReCALL, 24(2), 138-151.

https://doi.org/10.1017/S0958344012000031 
Sundqvist, P. (2019). Commercial-off-the-shelf games in the digital wild and L2 learner vocabulary. Language Learning \& Technology, 23(1), 87-113. https://doi.org/10125/44674

Sundqvist, P., \& Sylvén, L. K. (2016). Extramural English in the teaching and learning: From theory and research to practice. London: Palgrave Macmillan.

Sundqvist, P., \& Wikström, P. (2015). Out-of-school digital gameplay and in-school L2 English vocabulary outcomes. System, 51, 65-76. https://doi.org/10.1016/j.system.2015.04.001

Swain, M. (1985). Communicative competence: Some roles of comprehensible input and comprehensible output in its development. In S. Gass, \& C. Madden (Eds.), Input in second language acquisition (pp. 235-256). New York, NY: Newbury House.

Whiting, K. (2018). Jack Ma wants to go back to teaching. World Economic Forum. Retrieved from https://www.weforum.org/agenda/2018/09/jack-ma-wants-to-go-back-to-teaching/

Yashima, T. (2002). Willingness to communicate in a second language: The Japanese EFL context. The Modern Language Journal, 86(1), 54-66. https://doi.org/10.1111/1540-4781.00136

Yashima, T. (2009). International posture and the ideal L2 self in the Japanese EFL context. In Z. Dörnyei, \& E. Ushioda (Eds.), Motivation, language identity and the L2 self (pp. 144-192). Bristol: Multilingual Matters.

Zhong, Q. M. (2013). Understanding Chinese learners' willingness to communicate in a New Zealand ESL classroom: A multiple case study drawing on the theory of planned behavior. System, 41(3), 740751. https://doi.org/10.1016/j.system.2013.08.001

Corresponding author: Ju Seong Lee, jslee@eduhk.hk

Please cite as: Lee, J. S., \& Drajati, N. A. (2019). Affective variables and informal digital learning of English: Keys to willingness to communicate in a second language. Australasian Journal of Educational Technology, 35(5), 168-182. https://doi.org/10.14742/ajet.5177 


\section{Appendix A \\ Questionnaire}

\section{Part 1: IDLE Activities}

1. How often do you engage in the following receptive IDLE activities?

1 - never; 2 - rarely (once a week); 3 - sometimes (2 or 3 times per week); 4 - fairly often (once a day); 5 very often (many times per day)

1. I play games in English.

2. I listen to English language news programs online or TV.

3. I listen to songs in English.

4. I listen to English podcasts.

5. I watch English comics online or TV.

6. I watch sports events in English online or TV.

7. I watch English language movies or dramas with subtitles in English.

2. How often do you engage in the following productive IDLE activities?

1 - never; 2 - rarely (once a week); 3 - sometimes (2 or 3 times per week); 4 - fairly often (once a day); 5 very often (many times per day)

1. I chat with others in English via social media (e.g., Facebook, KaKaoTalk, Line, WeChat, WhatsApp).

2. I Skype with others in English.

3. I send an email to others in English.

4. I share English contents online.

5. I use technology to connect with native speakers of the language (e.g., American, British).

6. I use technology to connect with non-native speakers of English all over the world (e.g., Japanese, Chinese).

Part 2: L2 Willingness to communicate (L2 WTC)

1. How much are you willing to communicate in English in this situation?

1 - definitely not willing; 2 - probably not willing; 3 - perhaps willing; 4 - probably willing; 5 - definitely willing

1. When you are given a chance to talk freely in an English class.

2. When you have a chance to talk in front of the class in an English class.

3. When you have a group discussion in an English class.

4. When you have a chance to make a presentation in front of a large group.

5. When you find a friend standing before you in a line.

6. When you find an acquaintance standing before you in a line.

7. When you have a discussion with a small group of friends.

8. When you have a chance to talk within a small group of strangers.

\section{Part 3: Affective variables}

1. Please respond to the following statements on a 5-point Likert scale (grit).

1 - not like me at all; 2 - not much like me; 3 - somewhat like me; 4 - mostly like me; 5 -very much like me

1. I am a hard worker.

2. I finish whatever I begin.

3. I am diligent.

4. Setbacks don't discourage me.

5. New ideas and projects sometimes distract me from previous ones.

6. I have been obsessed with a certain idea or project for a short time but later lost interest.

7. I often set a goal but later choose to pursue a different one.

8. I have difficulty maintaining my focus on projects that take more than a few months to complete. 
2. Please respond to the following statements on a 5-point Likert scale (motivation).

1 - strongly disagree; 2 - disagree; 3 - neutral; 4 - agree; 5 - strongly agree

1. When it comes to studying English, I put much effort into it.

2. I actively think about what I have learned in my English class.

3. Considering how I study English, I can honestly say that I really try to learn English.

4. I don't really have a great desire to learn English.

5. During English class, I would like to have as much English as possible spoken.

6. If I had the opportunity to speak English outside of school, I would speak English as much as possible.

7. I find learning English very enjoyable.

8. English is an important subject to me in my college program.

3. Please respond to the following statements on a 5-point Likert scale (self-confidence).

1 - strongly disagree; 2 - disagree; 3 - neutral; 4 - agree; 5 - strongly agree

1. I am confident I can understand most of what my teacher says in English class.

2. I am confident I can use English vocabulary and expressions that I learned to interact with my teacher or friends.

3. I am confident I can ask and answer various questions in English.

4. I am confident I can talk about myself in English using sentences.

5. I am confident I can talk about what I did last weekend using English sentences.

6. I am confident I can do well in oral presentation in English.

7. I am confident I can order a meal in English at a restaurant.

8. I am confident I can ask for and give directions for location in English.

4. Please respond to the following statements on a 5-point Likert scale (L2 speaking anxiety). 1 - strongly disagree; 2 - disagree; 3 - neutral; 4 - agree; 5 - strongly agree

1. I feel nervous when I speak in English in front of other students.

2. I feel anxious if I am asked a question by my teacher.

3. When speaking in English, I can get so nervous that I forget things that I know.

4. I feel nervous when I am called upon to perform a task in English.

5. Even if I am well prepared for English class, I feel anxious about it.

6. I am afraid that the other students will laugh at me when I speak English. 